ベントス研連誌 $9 / 10 \quad 1975$

\title{
クモヒトデ類の食性
}

相 生 啓子

(東京大学 海洋研究所)

\section{Food habits of Ophiuroids}

\section{Keiko AlOI}

クモヒトデの食性に関しては胃内容物から二枚貝などの形のはっきりしたものが検出された例の 他は、水槽や野外での行動観察や実験により傍証的にその食性が知られている。

既住の研究からクモヒトデの餌としては次のものがあげられる（表１）。

1. 沈積有機デトライタス

Ophioglypha texturata

Ophiocomina nigra

Asteronyx loveni (young specimens)

Ophiocoma bollonsi

Ophiopholis aculeata

ophiurolepsis gelida

Blegvad 1914

Mortensen 1927

Mortensen 1927

Hurley 1959

Fell 1961

Fe11 1961

2. 植物遺䯓

Pectinura maculata (anthers of Nothofagus sp.)

Amphiophiura bullata (Sargassum)

Fe11 1952

Schoener \& Rowe 1970

3. 底生小動物

Ophiothrix fragilis

ophiopholis aculeata

Ophiocoma scolopendrina

Ophiura texturata

Mortensen 1927

Fe11 1961

Magnus 1964

Feder, H. in Thorson 1965

4. 海 藻

Ophionereis reticulata

ophiocomina nigra

May 1925

Mortensen 1927

Vevers 1956

Ophiothrix fragilis

Vevers 1956

5. 魚貝などの腐食

Ophiocomina nigra

Mortensen 1927 


\section{6. 有機愳濁物}

Astrotoma agassizii
Ophiocoma scolopendrina
Amphiura filiformis

Ophiothrix fragilis
Fel1 1961

Magus 1964

Buchanan 1964

Woodley 1967

Warner 1971

7. 動物プランクトン・マイクロネクトン

Asteronyx loveni

Astrotoma agassizii

Ophioceres incipiens

As trophyton muricatum
Mortensen 1927

Fell 1961

Fel1 1961

Davis 1966

8. 植物プランクトン

Ophiothrix fragilis

Roushdy \& Hansen 1960

9. 腔腸動物のポリプ

Gorgonocephalus caput-medusae

Gislen 1924

Asteronyx loveni

Gislen 1924

As trohamma tuberculatum

Fe11 1961

表 1. 既発表文献にみられるクモヒトデ類の食性

クモヒトデの搨食行動は腕の腹面に並んだ螌手状の管足を使って慨を集めると言われているが、三 つのタイプに分けられる。(1)、海底表面を掃くようにして集めるタイプ。(2)、水中に腕を延ばし振 り動かして水中の慨を集めるタイプ。(3)、タコヒトデやテッ゙ルモヅルのようにウミエラやサンゴに からみついて、別の腕で水中のプランクトンや小魚を捕え、同時に腔腸動物のポリプも食べている という会食なものもいる。

この他に、泥の中に潜る種類即ちinfaunaでは、Amphiodia barbarae (MacGinitie, 1949 ), Amphiodia occidentalis (Fontaine, 1965), Amphiura (Des Artes, 1910 ; Blegvad, 1914), epifaunaでは、Ophiura sarsi（MacGinitie，1949)が腕で掃くようにし、て海底の微 小生物、メイオベントスやデトライタスを食べている。

Fontaine (1965)はOphiocomina nigraが、海底から得られるありとあらゆる有機物を餌と している。これは他のepifauna のクモヒトデにも同様なことが言えることから、この多様な提食 行動と巾広い食物への適応性が、底生生物群集にお污る確固たる位置を占めるのに、おおいに貢献 していると述べている。

爪木崎・田の浦湾におけるニホンクモヒトデOphioplocus japonicus およびトウメクモヒト デOphiarachnella gorgoniaは両種とも非常にpopularな種類であるが、ホンダワラ、テングサ などの茂るガラモ場に限り生息することが判明した。特にガラモ場の転石の下などに多く生息場を 求めている。 
消化管内容物は数回の採集で一個体だけワカメの破片がそのまま出てきた例があるが極めて稀な 例と言える。その他は常に既に消化された物質が得られた。そこでその液状の物質を口を開けて蒸 溜水で流し出しフォルマリンで固定し試験管に数日間放置し沈澱させた後、ピペットでスライドグ ラスに採り影微鏡観察により胃内容物の調査を行った。

その結果は、顕微鏡下で確認できるものとして、海藻の破片、珠藻、暁脚類、二枚貝、有孔虫、 腺虫、錨状骨片、海綿骨片が得られた。しかしこれらのものが占める胃内容物の重量は、ほんの僅 かで、大部分は消化している途中の物質と考えられるもので表には白いブランクのままで示した（ 表 2 )。

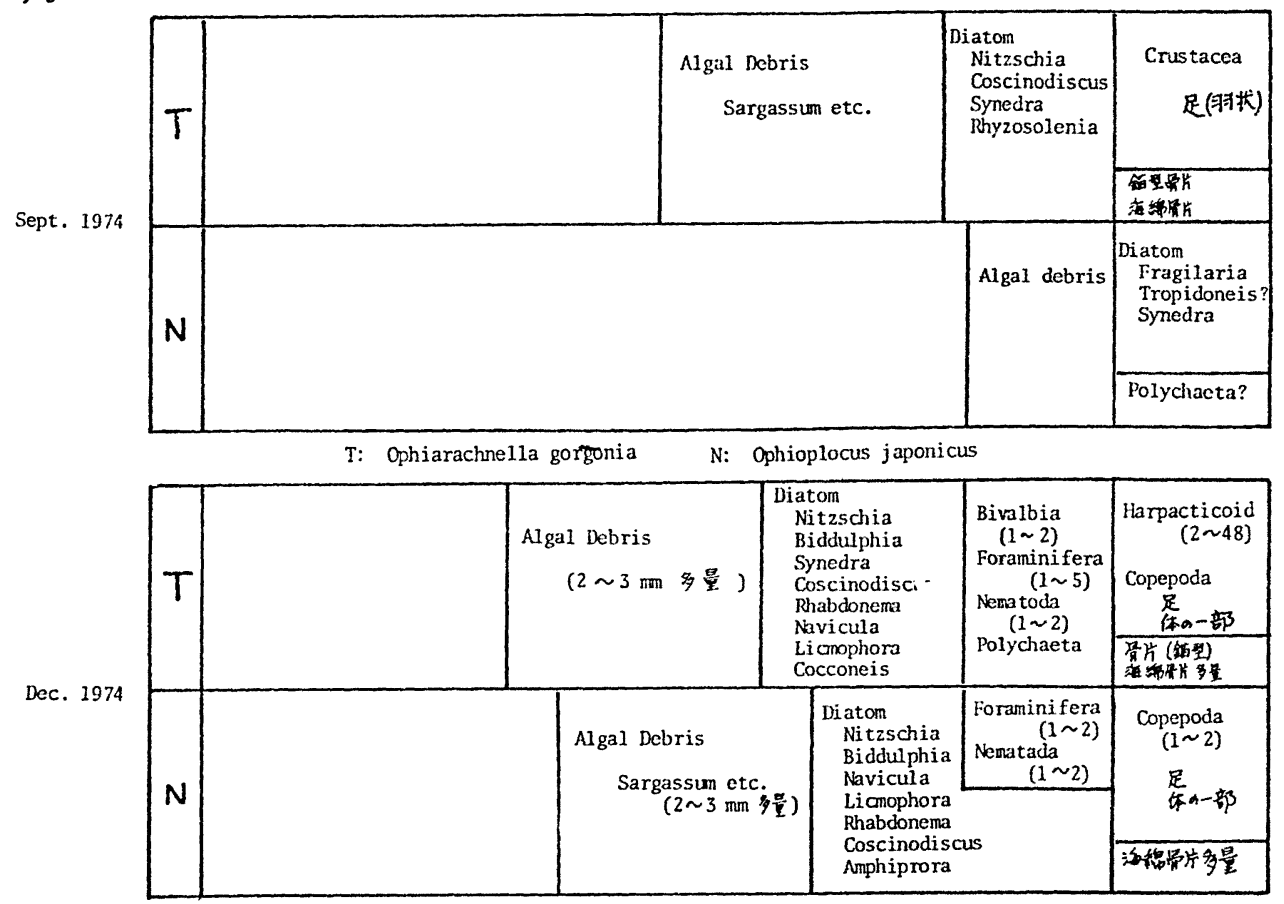

表2. クモヒトデの胃内容物 (田の浦滦)

クモヒトデの生息している場所から採集した沈積有機デトライタスを顕微鏡で見ると、海藻破片 動植物の遺骸と共に、二枚貝や理藻が認められる。胃内容物から砂粒や泥はあまり検出されない。 これらの知見からニホンクモヒトデもトウメクモヒトデも沈皘有機デトライタスを提食しているも のと結論できる。

ところでこの沈積有機デトライタスの表層部のバクテリアの数を測定してみると、8.0 0107 $8.5 \times 10^{10} / m \ell$ という值を示す。時にこの值は $10^{1} \sim 10^{2}$ 倍になることがありバクテリアが集落を 作っているものと推定される。デトライタスにはバクテリアの存在を無視できないので、胃内容物 中のブランクの部分と共に今後に残された課題であると考える。 


\section{REFERENCES}

Blegvad, H. 1914. Food and conditions of nourishment among the communities of invertebrate animals found on or in the sea bottom in Danish waters. Rep. Danish biol. Sta., 22, 41-78.

Buchanan, J. B. 1964. A comparative study of some features of the biology of Amphiura filiformis and Anphiura chiajei [Ophiuroidea] considered in relation to their distribution. J. mar. biol. Ass. U. K. 44, 565-576.

Davis, W. P. 1966. Observations on the biology of the ophiuroid Astrophyton muricatum. Bulletin of Marine Science, 16 (3), 435-444.

Des Artes, L. 1910. Ueber die Lebensweise von Amphiura chiajei unter Berücksichtigung der anatomischen Verhältnisse. Bergens Mus. Aarb., $12,1-10$.

Feder, H. 1965. In Thorson, G.: Life in the Sea, World University Library.

Fell, H. B. 1952. Echinoderms from Southern New Zealand. Zool. Pub. Vict. Univ. Wellington, 18, 1-37.

Fe11, H. B. 1961. The fauna of the Ross Sea. 1: Ophiuroidea. N. Z. Oceanographic Inst. Memoir, No. 18, 1-79.

Fe11, H. B. 1961. Bipolyarnii rod Ophiuroidea. Toporkovia Djakonov. Zool. Zh., 40, 1257-1258.

Fe11, H. B. 1966. The ecology of ophiuroids. In: Physiology of Echinodermata. A collective effort by a group of experts, edited by R. A. Boolootian. Dept. Zool., Univ. of Calif., 129-143.

Fontaine, A. R. 1965. The feeding mechanisms of the ophiuroid Ophiocomina nigra. J. Mar. biol. Ass. U. K., 45, 373-385.

Gislén, T. $\frac{1924}{192}$ Echinodem studies. Zool. Bidr. Uppsala, 9, 1-316.

Hurley, D. E. 1959. Some features of the benthic environment in Cook Strait. N. Z. J. Sci., 2, 137-147.

MacGinitie, G. E. 1949. The feeding of ophiurans. J. Ent. Zool., 41, 27-29.

Magnus, D. B. E. 1964. Gezeitenströmung und Nahrungsfiltration bei Ophiuren und Crinoiden. Helgol. Wiss. Meeresunters., 10, 104-117.

May, R. M. 1925. Les reactions sensorielles d'une ophiure (Ophionereis reticulata, Say). Bull. biol., 59, 372-402.

Mortensen, Th. 1927. Handbook of the echinoderms of the British Isles. Oxf. Univ. Press., ix +471 pp., 269 figs.

Reese, E. S. 1966. The complex behavior of echinoderm. In: Physiology of Echinodermata. A collective effort by a group of experts, edited by R. A. Boolootian. Dept. Zool., Univ. of Calif., 157-218.

Roushdy, G. M. \& V. K. Hansen 1960. Ophiuroids feeding on phytoplankton. Nature, Lond., 188, 517-518.

Schoener, A. \& G. T. Rowe 1970. Pelagic Sargassum and its presence among the deep-sea benthos. Deep Sea Res., 17, 923-925.

Vevers, H. G. 1956. Observations on the feeding mechanisms in some echinoderms. Proc. zool. Soc. Lond., 126, 484-485.

Warner, G. F. 1971. On the ecology of a dense bed of the brittle-star Ophiothrix fragilis. J. mar. biol. Ass. U. K., 51, 2-7-282.

Woodley, J. D. 1967. Problems in the ophiuroid water-vascular system. Symp. zool. Soc. Lond. No. 20,75-104. (In: Echinoderm Biology edited by N. Millott. Zool. Soc. Lond., Academic Press. 240pp.) 